\title{
Feasibility of Developing Direct Learning Models with a Life Based Learning Approach
}

\author{
*Annita Kastur ${ }^{1}$, Mustaji ${ }^{2}$, Yatim Riyanto ${ }^{3}$ \\ 1,2,3 3 Doctoral Program of Education Technology, Universitas Negeri Surabaya, Surabaya Indonesia
}

\begin{tabular}{|c|c|}
\hline (A) Check for updates open $\partial_{\text {Access }}$ (c) & DOI : https://doi.org/10.46245/ijorer.v1i3.63 \\
\hline Sections Info & ABSTRACT \\
\hline Article history: & This study aims to analyze the feasibility of the results of the learning \\
\hline Submitted: September 19, 2020 & model instrument, textbooks, student worksheets, assessment sheets, and \\
\hline Final Revised: September 28, 2020 & learning implementation plans. This study uses the Dick and Carey \\
\hline Accepted: October 22, 2020 & development model. There are 7 steps in Dick and Carey's learning, \\
\hline Published online: October 31, 2020 & including 1) Identifying learning objectives, 2) Conducting learning \\
\hline Keywords: & analysis, 3) Analyzing student characteristics and learning context, 4) \\
\hline Direct learning model & Formulating specific learning objectives, 5) Developing learning \\
\hline Feasibility & instruments, 6) Developing strategies learning, 7) Developing and \\
\hline Life based learning approach & selecting learning materials, 8) Designing and developing evaluation and \\
\hline 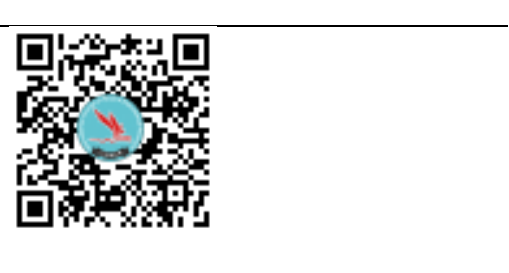 & $\begin{array}{l}\text { assessment, 9) Revising learning programs, 10) Implementing and } \\
\text { developing evaluations. Based on the results of the study showed that the } \\
\text { research instruments in the form of the results of the learning model, } \\
\text { textbooks, student worksheets, assessment sheets, and learning } \\
\text { implementation plans scored good criteria. The direct learning model } \\
\text { with a life-based learning approach is suitable for use as a learning model } \\
\text { in improving student learning outcomes. }\end{array}$ \\
\hline
\end{tabular}

\section{INTRODUCTION}

The world of education is required to be consistent in learning and improve abilities and be able to optimize learning models (Hamka \& Arsyad, 2015) both in formal and non-formal education (Guttierrez, 2015). Non-formal education is not only in the form of schools that have not received official recognition from the government, but there are courses and training institutions that are also very effective in helping the community gain life skills (Daniel et al., 2020).

Effective and different learning needs to be done by the teacher to find out the characteristics of each student (Rachman, 2015) and the material to be delivered. In supporting creativity in learning makeup, effective teacher guidance is needed so that students produce good creations in every drawing technique (Wahyuni \& Prabowo, 2020). The direct learning model can be passed by conveying competencies and learning objectives and requiring students to be teacher-centered (Astutik, 2020). The demonstration of material in learning has a very good impact on students in the classroom. A teacher is required to provide initial training guidance and can convey information step by step. At the end of learning, it is necessary to check the initial understanding of students by giving assignments or evaluating together with the learning material that has been delivered (Astutik, 2020). Through several stages of teacher-centered learning, it can improve student learning outcomes (Ilmika, 2017; Huet et al., 2011; Al-Faki \& Khamis, 2014).

In helping improve student learning outcomes it is necessary to do with learning strategies and techniques. In direct learning strategies, there are several stages of discussion that can be carried out by teachers in class (Yan et al., 2018). The discussion process can make the classroom atmosphere more lively (Lecun et al., 2015). Teaching 
The learning model of the life learning approach can contribute to classroom learning (Daniel et al., 2020). Learning with a life approach also believes that what we experience (Fatmawati et al., 2019) and learn outside the work environment is important (Miller, 2008). Life-based learning can provide to develop individual abilities. In this learning also makes students have a full willingness to meet their needs both in learning and in social. learning to work and not being limited by the place of work is a feature of the life learning approach. In this case, learning make-up can be done inside or outside the classroom as a place for students to look for creations or imagination in any material practice (Ilmika, 2017; Hairida, 2018; Hairida, 2017). Both the results and the practice of students are very necessary to train both.

Students who have slow learning characteristics need to have modules or examples according to the needs and circumstances of students to achieve optimal learning success to achieve competence for competency tests. The learning module can be done by creating material through power points (Hamka \& Arsyad, 2015; Abdi, 2014) or completing student worksheets. Some of these characters are owned by some students at the course and training institutions in Yogyakarta. The expected ability of students is to be able to meet the Indonesian national qualification standards. As well as the ability to do veiled bridal make-up without make-up. In this case, deep learning is needed (Daniel et al., 2020; Cheung \& Hew, 2011).

By paying attention to the objective conditions of students and the curriculum in the competency material for doing veiled Yogyakarta bridal make-up without make-up, in determining learning activities, related learning sources must be considered and the selection of appropriate learning models (Arsyad, 2017). The direct learning model with the Life Based Learning approach is specifically designed to support student learning outcomes (Daniel et al., 2020; Bakare \& Orji, 2019). Through declarative and procedural knowledge students are expected to be able to manage thought patterns and carry out gradual learning activities step by step (Wahyuni \& Prabowo, 2020; Agrippa et al., 2020; Arnika \& Kusrini, 2014; Safitri et al., 2013; Sultan \& Bancong, 2017).

By paying attention to these reasons and the objective conditions of students and the curriculum on the competency material of doing veiled Yogyakarta bridal make-up without make-up, in determining learning activities, related learning sources must be considered and the selection of learning models. To improve learning outcomes to do veiled bridal make-up in Yogyakarta, students certainly cannot be separated from all activities that improve the quality of learning outcomes of doing Yogyakarta veiled bridal make-up without make-up in the course institution, therefore it is necessary to apply a life-based learning model, as well as teaching and learning strategies. optimal and effective that can be implemented by educators without sacrificing interest and motivation of course students. Because learning is a process for students in building their ideas or understanding, teaching, and learning activities must provide opportunities for students to be actively involved in these learning activities. The direct learning model design scheme with a life-based learning approach in Figure 1. 


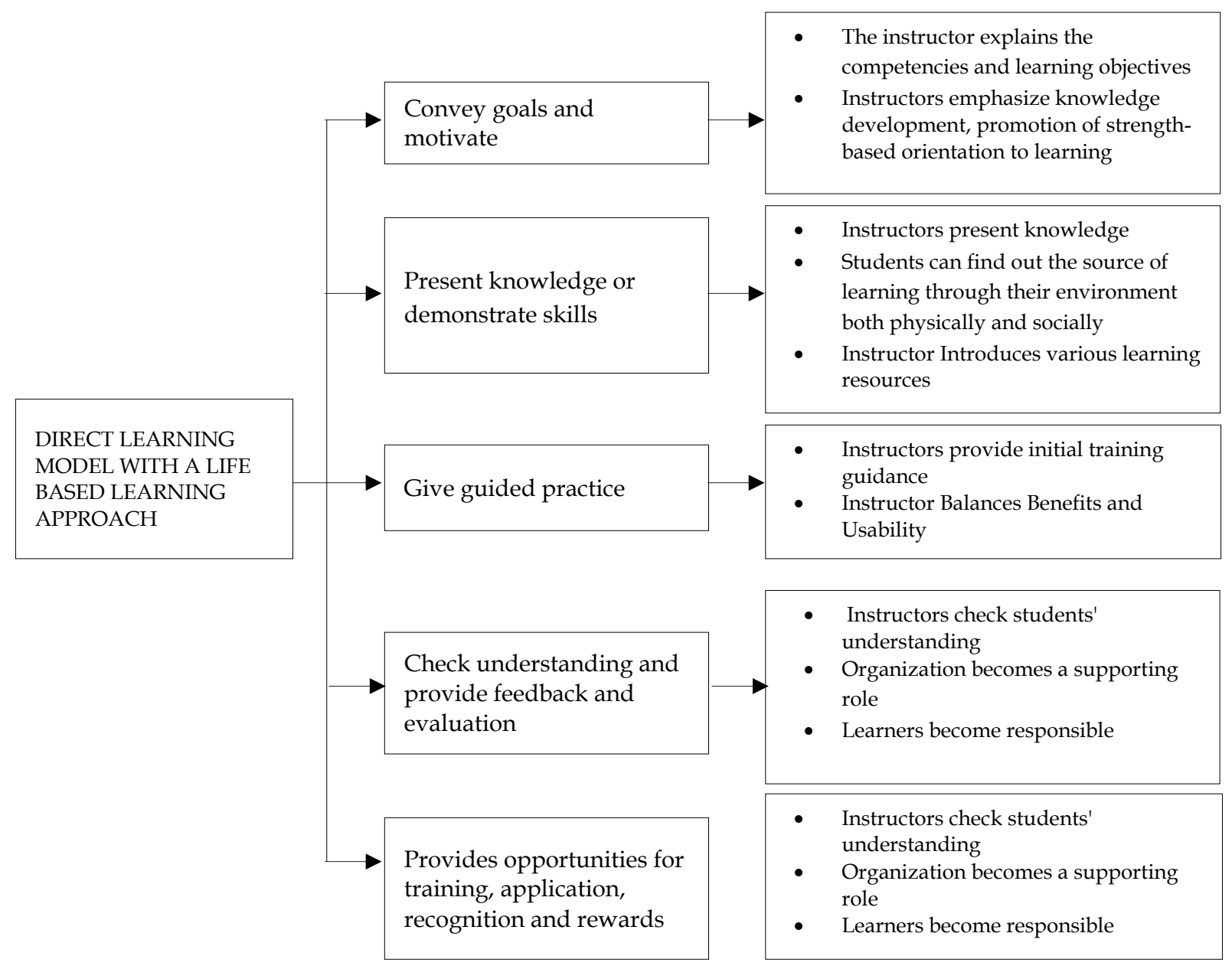

Figure 1. Direct learning model with approach.

The scheme above is an illustration of applying a direct learning model with a lifebased learning approach. Before implementing a direct learning model with a life-based learning approach according to the above scheme, it is necessary to first make the feasibility of the learning instrument. This study aims to analyze the feasibility of research instruments in the form of the results of learning models, textbooks, worksheets, assessment sheets, and lesson plans.

\section{RESEARCH METHOD \\ General Background}

The research model of developing this learning device uses a model prepared by Thiagarajan, the 4D model. This model consists of 4 stages of development, namely defining, designing, developing, and disseminating. An overview of this development research design can be seen in Figure 1. This study uses the Dick and Carey development model. The development model refers to the steps of a systems approach model by understanding the character of students (Nugroho et al., 2018). There are 7 steps in Dick and Carey's learning, including 1) Identifying learning objectives or program competencies, 2) Conducting instructional or learning analysis, 3) Analyzing student characteristics and learning context, 4) Formulating specific learning objectives and program indicators, 5) Developing learning instruments, 6) Developing learning strategies, 7) Developing and selecting learning materials, 8) Designing and developing 
formative evaluations, 9) Revising learning programs, 10) Implementing and developing summative evaluations. In this study, the feasibility of developing a learning model with a life-based learning approach using several instruments, including the results of the learning model, textbooks, student worksheets, assessment sheets, and lesson plans.

\section{The Technique of Analyzing the Feasibility of A Learning Model with A Life-Based Learning Approach}

At this stage, it is carried out by analyzing descriptive statistical data using the percentage of the results of the expert test validation questionnaire. By using the formula:

$$
\text { PSA }=\frac{\text { Lalternative answers are chosen by each aspect }}{\text { Lalternative ideal answer for every aspect }} X 100 \%
$$

In giving meaning to percentage figures, as a result of calculations using this formula which will be linked to determining whether this media should be revised or not, the following criteria will be used:

Table 1. Score criteria.

\begin{tabular}{cc}
\hline Percentage & Criteria \\
\hline $81 \%-100 \%$ & Very good \\
$61 \%-80 \%$ & Good \\
$41 \%-60 \%$ & Enough good \\
$21 \%-40 \%$ & Not good \\
$0 \%-20 \%$ & Very not good \\
\hline
\end{tabular}

\section{RESULTS AND DISCUSSION}

Before implementing the life-based learning development model, all instruments need to be validated and assessed. The following are the results of the learning model validation.

Table 2. Learning model results.

\begin{tabular}{clcl}
\hline No. & Assessment Aspects & $\begin{array}{c}\text { Average } \\
\text { value }\end{array}$ & $\begin{array}{c}\text { Rating } \\
\text { category }\end{array}$ \\
\hline $\mathbf{1}$ & Learning steps & 3,6 & Good \\
$\mathbf{2}$ & Social System & 3,75 & Good \\
$\mathbf{3}$ & Principle of Reaction & 4 & Good \\
$\mathbf{4}$ & Support System & 4 & Good \\
$\mathbf{5}$ & Instructional Impact & 4 & Good \\
$\mathbf{6}$ & Accompaniment Impact & 3,6 & Good \\
\hline & Average value & 3,8 & Good \\
\hline
\end{tabular}

From Table 2, it can be seen that the average result of the assessment by the validator resulted in a good category. In this case, it shows that this learning model can be tested on students as a support for the learning process. Through the development of a learning model able to make students more focused on learning goals (Azwar et al., 2017). In line with research from (Wahyuni \& Prabowo, 2020) states that the results of 
the validation of direct learning tools are in a good category so that they can be tested on students in the learning process. The results of the assessment of the lesson plan validation of experts and practitioners, expert assessment is carried out by Learning Experts II. The results of the assessment of the lesson plan instrument are briefly presented in Table 3.

Table 3. Validation results lesson plan.

\begin{tabular}{clcl}
\hline No & \multicolumn{1}{c}{ Assessment Aspects } & $\begin{array}{c}\text { Average } \\
\text { value }\end{array}$ & $\begin{array}{c}\text { Rating } \\
\text { category }\end{array}$ \\
\hline $\mathbf{1}$ & Learning objectives & 4 & Good \\
$\mathbf{2}$ & Learning Activities & 4 & Good \\
$\mathbf{3}$ & Core activities & 3.5 & Good \\
$\mathbf{4}$ & $\begin{array}{l}\text { Student Worksheet } \\
\text { teaching materials }\end{array}$ & 4 & Good \\
\hline & Average value & 3.9 & Good \\
\hline
\end{tabular}

Table 3 above shows that the results of the lesson plan assessment include aspects of learning objectives, learning activities, proficiency, core activities, student books, and student worksheets have an average of 3.9 so that the lesson plan that has been developed is in a good category. Supported by Sarigih \& Elvis (2015) states that the procedure for delivering teaching materials to students is categorized as good. By assessing the results of the validation of a valid learning plan, it can have a positive impact on learning physics through student activities to be good (Astutik, 2020). Then will analyze the results of the validation of students' books.

Tabel 4. Validation of student book.

\begin{tabular}{clcc}
\hline No. & \multicolumn{1}{c}{ Assessment Aspects } & $\begin{array}{c}\text { Average } \\
\text { value }\end{array}$ & $\begin{array}{c}\text { Rating } \\
\text { category }\end{array}$ \\
\hline $\mathbf{1}$ & $\begin{array}{l}\text { Suitability of material and } \\
\text { learning objectives }\end{array}$ & 4 & Good \\
$\mathbf{2}$ & Science words and terms & 3.5 & Good \\
$\mathbf{3}$ & Truth of concept & 3.5 & Good \\
$\mathbf{4}$ & Concept sequence & 3.5 & Good \\
$\mathbf{5}$ & Image supporting material & 3.5 & Good \\
$\mathbf{6}$ & Language readability & 3.5 & Good \\
$\mathbf{7}$ & References & 3.5 & Good \\
\hline & Average value & 3.6 & Good \\
\hline
\end{tabular}

Then for the validity instrument that has been generated in the table above, it shows that the average feasibility of the student textbook has a good value category. This is in line with Daniel et al (2020) through direct case-based science learning which can improve student literacy.

Table 5. Results of Student worksheet validation.

\begin{tabular}{clcc}
\hline No & \multicolumn{1}{c}{$\begin{array}{c}\text { Assessment } \\
\text { Aspects }\end{array}$} & Average value & Rating category \\
\hline $\mathbf{1}$ & Instructions & 4 & Good \\
$\mathbf{2}$ & Feasibility Konten & 3.8 & Good \\
$\mathbf{3}$ & Prosedur & 4 & Good \\
$\mathbf{4}$ & Question & 4 & Good \\
\hline & Average value & 3,9 & Good \\
\hline
\end{tabular}


Table 5 above shows that the results of the assessment of student worksheets covering aspects of instructions, content feasibility, procedures, and questions have an average of 3.9 so that the worksheets of students that have been developed are in a good category. Learning tools are in the effective category (Rachman, 2015).

Table 6. Validation results of performance appraisal and product appraisal sheets.

\begin{tabular}{cllcc}
\hline No & Device Type & Assessment Aspects & $\begin{array}{c}\text { Average } \\
\text { value }\end{array}$ & $\begin{array}{c}\text { Rating } \\
\text { category }\end{array}$ \\
\hline $\mathbf{1}$ & Performance & Conditions are & 4 & Good \\
& Appraisal & disabled & & \\
& Sheet & Content feasibility & 4 & Good \\
& & Procedure & 4 & Good \\
& & Question & 4 & Good \\
\multirow{2}{*}{ Product } & Average value & 4 & Good \\
& Assessment & Material realm & 4 & Good \\
& Sheet & Lanstruction realm & 4 & Good \\
\hline & & Average value & 4 & Good \\
\hline
\end{tabular}

Based on the results of the validation of the performance appraisal sheet and the product appraisal by the lecturer validator, the result is that the average assessment category is good. In this case, it states that the assessment instrument is feasible to be tested on students. Learning tools that have been developed can effectively increase the representative abilities of students (Azwar et al., 2017). Based on the results of several research instruments that have been analyzed above, we can see that the category average is good. This also applies to the evaluation of other instrument validation results, such as validation of the Learning Implementation Plan and validation of student worksheets. All learning tools that have been validated with good grades can be tested on the research sample (Wulandari, 2019). Very valid learning tools can be used in an effective learning process (Wahyudi \& Prabowo, 2020).

\section{The Feasibility of a Direct Learning Model With A Life-Based Learning Approach}

In this study, the purpose of this study was to determine the feasibility of a direct learning model with a life-based learning approach to improve student learning outcomes. The feasibility test carried out includes the test of learning design experts I, learning design experts II, learning material experts, learning media experts, and learning evaluation experts using a questionnaire/questionnaire method. The following shows the results of the feasibility questionnaire for the direct learning model with a life-based learning approach in Table 7.

Table 7. Feasibility of learning model.

\begin{tabular}{clc}
\hline No. & \multicolumn{1}{c}{ Expert } & Average \\
\hline $\mathbf{1}$ & Learning design I & 3,8 \\
$\mathbf{2}$ & Learning design II & 3.9 \\
$\mathbf{3}$ & Theory I & 3,6 \\
$\mathbf{4}$ & Theory II & 3,9 \\
$\mathbf{5}$ & Evaluation & 4 \\
\hline \multicolumn{2}{c}{ Overall total average } & 3,8 \\
\hline
\end{tabular}


Based on the results of the assessment of the four experts, namely (1) learning design expert I who gave an assessment related to the learning model developed obtained an average result of 3.8 , (2) learning expert II who gave an assessment related to the learning implementation plan developed obtained average results -averaged 3,9, (3) material experts who gave an assessment related to the teaching materials developed obtained an average result of 3.6, (4) material experts II who gave assessments related to the worksheets of students developed obtained average results. an average of 3.9, and (5) the evaluation expert who assessed the student assessment sheet obtained an average result of 4 . So it can be concluded that from all the trials experts got an average score of 3.8. Based on the results of these calculations, if faced with the criteria, the average score is in the valid category.

In living life in the current era of knowledge, educational principles are needed that can accommodate the interests of students so that they can survive in the era of knowledge. The intended ability not only consists of skills to find a job, but also skills to be able to overcome difficulties that occur in their life (Lyer, 2017). follow the lesson. Through the feasibility of the research instrument, it can provide fluency and be able to improve the skills of students when the life-based learning model is applied (Fawait, 2017).

The learning model in this research can be studied according to the explanation from UNESCO, namely by the existence of five pillars which reads how to know, how to do, how to be, how to live together, and how to learn. The five pillars of education are signs as well as indicators of educational success recommended by UNESCO. One of the learning paradigms under the five pillars of UNESCO education is life-based learning. Life-based learning can be said to be under the five pillars of UNESCO education because the ultimate goal of life-based learning is in line with the UNESCO pillar of education, which is to form the capabilities of students, which include life skills. According to the Ministry of National Education, life skills as the core of competence and educational outcomes are skills that a person has to be brave enough to face the problems of life and life naturally without feeling pressured, then proactively and creatively seek and find solutions so that they are finally able to overcome existing problems.

Life-based learning recognizes that individuals have knowledge, skills, and abilities that organizations cannot always see and acknowledge, even though they make a significant contribution to life in the organization. Learning with a life approach also believes that what we experience and discuss outside the work environment is important. Learning with a life approach focuses on direct learning (Nordin et al., 2020) with a subject approach and learning with a performance approach. Such conditions offer the potential for developing a framework for skills development.

In a life-based learning approach, the process of students must also be able to illustrate or model and even conduct experiments according to the intended competencies. The learning evaluation that is assessed is a process that includes correctness of work methods, thoroughness, accuracy, tenacity at work, and so on. Direct learning models of life-based learning (especially demonstration activities) can provide a challenge to consider the gap between theory (what should be) and observation (what happens). With a life-based learning model approach that focuses on 
developing capabilities in the era of science to contribute to people's welfare and happiness.

Learning by bringing students closer to real-life has been able to improve student learning outcomes in learning. Nordin et al. (2020) stated that learning by focusing on daily life skills can be easily integrated into classes with learning disabilities. Life Skills competencies are indispensable in many areas (Abney \& Wagman, 2015), including work, further education, home and family, vacation, health, community involvement (Jacobs et al., 2012), interpersonal relationships, and personal development.

\section{CONCLUSIONS}

Based on the research results, it can be concluded that the research instruments in the form of the results of the learning model, textbooks, worksheets, assessment sheets, and learning implementation plans meet the good criteria. The direct learning model with a life-based learning approach is suitable for use as a learning model in improving student learning outcomes. This is indicated by the results of the expert's assessment who meet good qualifications. This research is limited to conducting a feasibility test of a direct learning model research instrument with a life-based learning approach. For future research, the application of learning using this research instrument can be tested on students who are following the conditions and criteria for this instrument.

\section{ACKNOWLEDGEMENTS}

The research team thanks all those who have helped carry out direct learning in this life-based learning approach.

\section{REFERENCES}

Abdi, A. (2014). The effect of inquiry-based learning method on students' academic achievement in science course. University Journal Educations Research, 2(1), 37-41.

Abney, D.H., \& Wagman, J.B. (2015). Direct learning in auditory perception: An information-space analysis of auditory perceptual learning of object length. Ecological Psychology, 274, 335-356.

Agrippa, K., Dehop, S., Makaliwe, N., \& Makaliwe, N. (2020). Penerapan model pembelajaran langsung untuk meningkatkan hasil belajar siswa pada mata pelajaran IPS Terpadu kelas IX SMP N 1 Tatapaan. Jurnal Pendidikan Ekonomi, 5(2), 20-28.

Al-Faki, I.M., \& Khamis, A.H.A. (2014). Difficulties facing teachers in using interactive whiteboards in their classes. American International Journal of Social Sciences, 3(2), 136-158.

Arnika, D., \& Kusrini. (2014). Penerapan model pembelajaran langsung (direct instruction) dengan metode kumon pada materi persamaan lingkaran di SMAN-1 Krian. MathEdunesa, 1(3), 1-6.

Arsyad, A. (2017). Median pembelajaran. Jakarta: Rajawali Pers.

Astutik, E.Y. (2020). Penerapan model pembelajaran langsung (direct instruction) pada kompetensi dasar perawatan kulit wajah secara manual di SMK Negeri 3 Kediri. E-Jurnal, 9(4), 82-90.

Azwar., Surya, E., \& Saragih, S. (2017). Development of learning devices based on contextual teaching and learning model based on the context of aceh cultural to 
improve mathematical representation and self-efficacy ability of SMAN 1 Peureulak students. Journal of Education and Practice, 8(2), 186-195.

Bakare, J., \& Orji, C.T. (2019). Effects of reciprocal peer tutoring and direct learning environment on sophomores' academic achievement in electronic and computer fundamentals. Education Information Technology, 24, 1035-1055.

Cheung, W.C., \& Hew, K.F. (2011). Design and evaluation of two blended learning approaches: Lessons learned. Australian Journal of Educational Technology, 8, 13191337.

Daniell, C.A., \& Dina, G.M. (2020). The life sciences learning center: An evolving model for a sustainable STEM Outreach Program. Journal STEM Outreach, 3(2), 1-23.

Fatmawati, Fayanto. S., Sukariasih, L., \& Retnawati, H. (2019). Investigating the effectiveness of inquiry learning and direct learning models toward physics learning. Advances in Social Science, Education and Humanities Research, 317, 260 265.

Fawait, A. (2017). Life-based learning dengan menggunakan pendekatan living value instruction dalam tradisi akademik pesantren. 1st Annual Conference for Muslim Scholars. 698-707.

Gutierrez, E. (2015). MOOC \& B-learning: Students' barriers and satisfaction in formal and non-formal learning environments. Journal of Interactive Online Learning, 13(3), 88-111.

Hairida, H. (2018). The development of blended learning media for flipped classroom model on direct learning in process evaluation courses and chemistry learning outcomes. Advances in Social Science, Education and Humanities Research, 295, 211217.

Hairida. (2017). Keterampilan calon guru kimia dalam mengembangkan alternative assessment. Jurnal Pengajaran MIPA, 22(1), 1-7.

Hamka, L., \& Arsyad. M. N. (2016). Keefektifan penerapan model pembelajaran langsung pada materi sistem gerak di SMA Negeri 1 Donri-Donri. Jurnal Bionature, 16(1), 58-64.

Huet, M., Jacobs, D. M., Camachon, C., Missenard, O., Gray, R., \& Montagne, G. (2011). The education of attention as explanation of variability-of-practice effects: Learning the final approach phase in a flight simulator. Journal of Experimental Psychology: Human Perception and Performance, 37, 1841-1854.

Ilmika, C.F. (2017). Penerapan model pembelajaran langsung pada kompetensi penataan sanggul pusung tagel Di SMK Negeri 3 Blitar. Jurnal Tata Rias Jurnal, 6(3), 32-37.

Jacobs, D.M., Vaz, D.V., \& Michaels, C.F. (2012). The learning of visually guided action: An information-space analysis of pole balancing. Journal of Experimental Psychology: Human Perception and Performance, 3(8), 1215-1227.

Lecun, Y., Bengio, Y., \& Hinton, G. (2015). Deep learning. Nature, 521, 436-444.

Lyer, R.B. (2017). Value-based education: Professional development vital towards effective integration. Journal of Research \& Method in Education, 1(1), 17-20.

Miller, D.R. (2008). Life based learning: Designing professional development for the knowledge era. Australia. (Online).

Nordin, L., Razak, N.Z.A., \& Kassim, R. (2020). Direct learning strategies employed in learning english among students of engineering technology. Journal of Critical Reviews, 7(8), 162-167. 
Nugroho, A., \& Suliyanah. (2018). Pengembangan KIT praktikum pegas berbasis pembelajaran guided inquiry pada materi elastisitas sebagai media pembelajaran siswa SMA. Jurnal Pendidikan Fisika, 7(2), 235-360.

Rachman, F. (2015). Pengembangan perangkat pembelajaran dasar dan pengukuran listrik dengan media circuit wizard menggunakan model pembelajaran langsung (direct instructions) berbasis kurikulum 2013. Jurnal Pendidikan Teknik Elektro, 14(2), 469-476.

Safitri, I., Hartono, B., Halimah, H. (2013). Penerapan multiple intelligences melalui model pembelajaran langsung terhadap sikap dan hasil belajar kimia peserta didik di SMA Negeri 1 Tellu Limpoe. Jurnal Pendidikan IPA Indonesia, 2(2), 156-160.

Saragih, S., \& Elvis, N. (2015). Developing student-centered learning model to improve high order mathematical thinking ability. International Education Studies, 8(6), 104112.

Sultan, A.D., \& Bancong, H. (2017). Pengaruh pendekatan multiple intelligences melalui model pembelajaran langsung terhadap sikap dan hasil belajar fisika peserta didik kelas XI IPA SMA Negeri 11 Makassar. Jurnal Pendidikan Fisika, 5 (1), 51-60.

Wahyuni, E., \& Prabowo. (2020). Validitasi perangkat pembelajaran model direct instruction berbantu KIT EHUS20 pada materi elastisitas. Inovasi Pendidikan Fisika, 9 (1), 18-20.

Wulandari, D., \& Madlazim. (2019). Penerapan model pembelajaran inkuiri terbimbing metode STEM untuk meningkatkan keterampilan berfikir kreatif pada materi pemanasan global. Inovasi Pendidikan Fisika, 8(3), 779-783.

Yan, H., Wan, J., Zhang, C., Tang, S., Hua, Q., \& Wang, Z. (2018). Industrial big data analytics for prediction of remaining useful life based on deep learning. IEE Access, 6, 17190-17197.

\footnotetext{
*Dr. Annita Kastur (Corresponding Author)

Universitas Negeri Surabaya, Indonesia

Jl. Raya Kampus Unesa, Lidah Wetan, Kec. Lakarsantri, Kota SBY, Jawa Timur 60213 Indonesia

Email: annitakastur16070996008@mhs.unesa.ac.id

Prof. Dr. Mustaji

Universitas Negeri Surabaya, Indonesia

Jl. Komplek Universitas Negeri Surabaya Gedung D1, Jl. Ketintang Sel. No.Kel, Ketintang, Kec. Gayungan,

Kota SBY, Jawa Timur 60231 Indonesia

Email: mustaji@unesa.ac.id

Prof. Dr. Yatim Riyanto

Universitas Negeri Surabaya, Indonesia

Jl. Komplek Universitas Negeri Surabaya Gedung D1, Jl. Ketintang Sel. No.Kel, Ketintang, Kec. Gayungan, Kota SBY, Jawa Timur 60231 Indonesia

Email: yatimriyanto@unesa.ac.id
} 